\title{
CHARACTERISTICS OF FORAGING HABITATS AND CHICK FOOD PROVISIONING BY TROPICAL ROSEATE TERNS ${ }^{1}$
}

\author{
JAIME A. RAMOS \\ Instituto Politécnico de Bragança, Escola Superior Agrária, Departamento de Biologia, \\ Campus de Santa Apolónia, 5300 Bragança, Portugal, e-mail: jramos@ipb.pt
}

\begin{abstract}
I studied tropical Roseate Terns (Sterna dougallii) on Aride Island, Seychelles, between 1997-1999. Productivity in 1998 was 0.58 fledglings/breeding pair, and in 1999 no young fledged. Roseate Terns on Aride concentrated their foraging along the coastline exposed to prevailing winds, with flock size over this area being significantly correlated with amount of food offered to chicks. In 1998, Lesser Noddies (Anous tenuirostris) were present in $91 \%$ of the Roseate Tern flocks, but in 1999 occurred in only $32 \%$. During the 1998 successful breeding season, Roseate Terns were associated with dense flocks of Lesser Noddies over predatory fish, whereas during the 1999 failure season most Roseate Tern flocks were either monospecific or mixed with Fairy Terns (Gygis alba), and without predatory fish. The mean flock size of Roseate Terns ( $82 \mathrm{vs.} 6$ birds) and the rate of foraging attempts ( 8.3 vs. 2.8 attempts $\left.\min ^{-1}\right)$ were significantly greater in association with predatory fish. Mullidae (Parupeneus or Mulloidichthys) were the primary prey taken by Roseate Terns, and alternative sources of food were apparently scarce. The high daily variations in the amount of food brought to chicks, intermediate periods of low food delivery, and an apparent seasonal decline in the amount of food brought to the colony suggest that food is unpredictable on a daily and seasonal basis. Absence of predatory fish may explain complete breeding failures and periods of low food delivery, but the importance of other factors is unknown. Information on the ecology and movement patterns of predatory fish around Aride Island is needed to assist the conservation of the Roseate Terns.
\end{abstract}

Key words: chick provisioning, diet, food shortage, foraging ecology, multispecies flocks, Roseate Tern, Sterna dougallii.

\section{INTRODUCTION}

An animal should forage primarily in a patch that maximizes its capture success (Krebs and Kacelnik 1991). The most important foraging patches for tropical seabirds are characterized by association with subsurface predators (Ballance and Pitman 1999). In shoals of prey driven to the surface by predatory fish, food is probably superabundant for seabirds, although spatially and temporally unpredictable.

When compared to temperate populations, seasonal patterns of food availability for tropical seabird populations are difficult to ascertain. In some areas, dramatic reductions in food availability occur during years of the El Niño Southern Oscillation, leading to catastrophic breeding failures (Nelson 1983, Megyesi and Griffin 1996). However, even during non El Niño years, breeding seasons may be characterized by periods of food shortage, which may lead to breeding failures (Feare 1976, Nelson 1983, Ramos, in press). The reasons behind these food short-

\footnotetext{
${ }^{1}$ Received 29 November 1999. Accepted 22 June 2000.
}

ages remain unknown, and may not be necessarily related to absolute abundance of prey. Trophic relationships among tropical seabirds may be quite complex, involving underwater predators, multispecies flocks, and other unknown factors (Au and Pitman 1986, Ballance and Pitman 1999).

Throughout their range, Roseate Terns (Sterna dougallii) forage in habitats where prey availability is high. Temperate populations feed over tide rips and shoals (Safina 1990b), upwelling areas (Ramos et al. 1998b), and predatory fish (Safina 1990a) that force prey to the surface. Tropical populations have received much less attention. However, Shealer (1996) found that Roseate Terns in the Caribbean are attracted to biotic features (Brown Pelicans Pelecanus occidentalis and predatory fish) driving prey close to the water surface. Complete breeding failures are uncommon for tropical tern populations in the Caribbean, including Roseate Terns (Morris and Chardine 1992, Shealer 1995). In contrast, breeding failures occur frequently in the Indian and Pacific Oceans (Milton et al. 1996, Ramos, in press). Foraging success in relation to habitat 
features and seasonal variations in chick provisioning are still poorly understood in many tropical seabird species. Relationships between these variables may help to elucidate the unknown factors involved in breeding failures. This information is particularly important for Roseate Terns in the Indian Ocean, the World's stronghold of this endangered species (Gochfeld 1983).

I examine characteristics of foraging habitats of tropical Roseate Terns on Aride Island, Seychelles, during three breeding seasons, determine prey capture attempts in relation to habitat features, and describe annual variation in diet and seasonal variation in chick provisioning in order to examine the following questions: (1) What are the main characteristics of foraging habitats and their relationships to foraging frequency and prey delivered to nestlings? (2) What are the most likely reasons for periodic food shortages during a breeding season?

\section{METHODS}

Roseate Terns were studied on Aride Island $\left(4^{\circ} 10^{\prime} \mathrm{S}, 55^{\circ} 40^{\prime} \mathrm{E}\right)$, Seychelles during June-July 1997-1999. Aride belongs to the central Seychelles group (Fig. 1), a group of granitic islands situated on a submarine bank less than $200 \mathrm{~m}$ deep, where depths of 44-65 m extend for about $43,000 \mathrm{~km}^{2}$ (Braithwaite 1984). Most seabird species in central Seychelles, including Roseate Terns, breed during the southeast monsoon (May-September), when seasonal movements of oceanic currents may be associated with higher productivity and migrations of tuna that make prey available to seabirds (Diamond and PrysJones 1986).

Roseate Terns arrived in early to mid-May, laid eggs in late May to mid-June, under a canopy of Pisonia trees (Ramos 1998a), and departed in late July-early August. In 1997, I located foraging flocks around Aride whenever observed, in order to plan subsequent characterization of foraging habitats and to define important foraging areas. In 1998 and 1999, four points, Owl site 16 (west), Viewpoint (north), Richard's Rock (northeast), and Coral Beach (southeast) were visited at 7-day intervals between 14:00-16:00 to record all foraging flocks (Fig. 1). These are referred to here as weekly observed flocks. I scanned the area for flocks by using $8 \times 42$ binoculars and telescope, and the following variables were recorded for each flock detected: (1) habitat (reef: up to $200 \mathrm{~m}$ from the coast, the marked reserve boundary; blue-water: dark-blue water $>200 \mathrm{~m}$ from the coast), (2) number of individuals of each species, (3) density of the flock (loose: distance between foraging birds $>20 \mathrm{~m}$; moderate: distance between foraging birds between 5-20 m; and dense: distance between foraging birds $<5 \mathrm{~m}$ ), and (4) presence or absence of predatory fish (which could only be detected out to Bobby Island, an islet approximately $500 \mathrm{~m}$ from the Aride coral beach). The presence of predatory fish was based on their feeding activity at the surface.

Preliminary observations in 1997 suggested that the majority of foraging flocks with Roseate Terns occurred along the south coast and could be observed from the Coral Beach viewpoint. This point was visited daily at $06: 45$, between 11:30-12:00, and 15:30-16:00 in 1998 and 1999. The area was scanned with telescope and binoculars, and all foraging flocks with Roseate Terns were registered and characterized using the variables defined above. I will refer to these as daily observed flocks. In these and other flocks located opportunistically, I recorded the duration (with a stopwatch) and number of prey capture attempts of individuals during feeding bouts. A single individual was selected and observed with binoculars for the duration of its feeding bout or until the bird was lost from sight (Shealer and Burger 1993). Roseate Terns plunge dive from variable heights and feeding attempts are relatively easy to quantify. In dense flocks, some individuals could be followed only for 5-10 sec. In order to eliminate the high contribution that a single foraging attempt would have in an individual's performance followed for such a short period, only birds followed for 25 $\mathrm{sec}$ or more were included in the analyses. Each trial was standardized; i.e., feeding attempts were expressed per minute.

To determine seasonal variation in food availability, the same 5 to 12 chicks were watched daily throughout the breeding seasons of 1997 and 1998 from 07:00-09:00 using binoculars. These were single-chick broods of known age situated $0.5-10 \mathrm{~m}$ away from a permanent hide. Small shelters made of stones (to encourage chicks to stay at their nest) were constructed for 10 chicks aged 0-2 days in 1997; each site was marked with a numbered flag and 5 chicks were color-marked on the head. Chicks remained at 

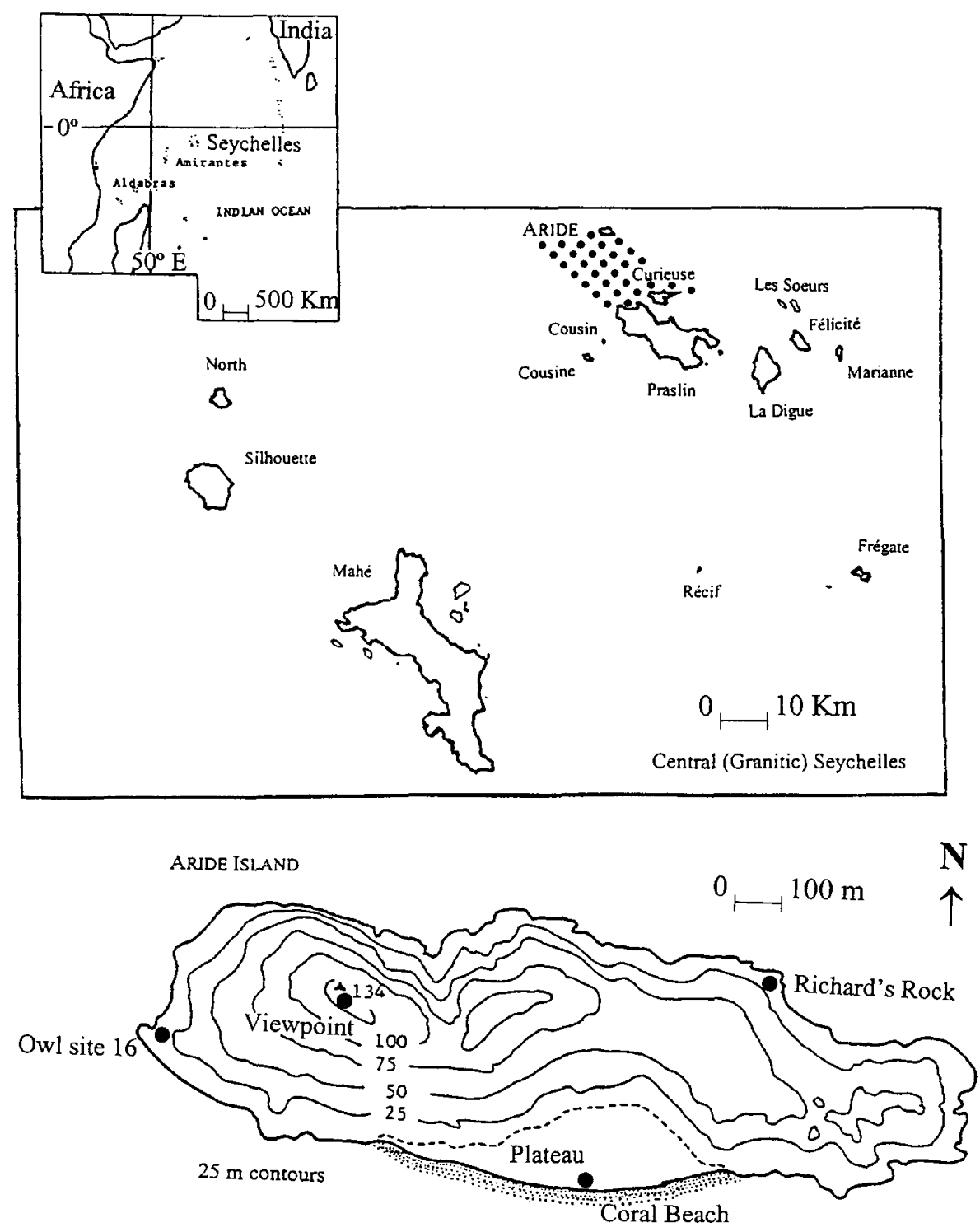

FIGURE 1. Aride Island, showing (insets) its location in the Indian Ocean and in the Seychelles group, and its topography (after Warman and Todd 1984). The dots on the Central (Granitic) Seychelles inset represent the area where most foraging flocks were observed. On the Aride Island map, the solid circles are the viewpoints visited to record foraging flocks.

their nest sites and could be followed easily. No shelters and flags were used in 1998.

I recorded whether prey were delivered to chicks, dropped, or robbed by adult terns. Observed prey were identified to family by comparison with specimens dropped or regurgitated by Roseate Terns, Lesser Noddies (Anous tenuirostris), or Fairy Terns (Gygis alba); these be- ing the most common species observed in the mixed feeding-flocks with Roseate Terns. Dropped prey were identified using Smith and Heemstra's (1986) guide and stored in alcohol. Mullids were identified to genera by Tony Gill of the Natural History Museum (London). Fish species were distinctive in shape or color and identical to collected specimens, therefore I be- 
TABLE 1. Frequency of occurrence and mean number of individuals per flock by seabird species in foraging flocks with Roseate Terns on Aride in 1998 ( $n=64$ flocks) and 1999 ( $n=22$ flocks).

\begin{tabular}{|c|c|c|c|c|c|c|}
\hline \multirow[b]{2}{*}{ Species } & \multicolumn{2}{|c|}{ No. flocks } & \multicolumn{2}{|c|}{$\begin{array}{c}\text { Frequency of } \\
\text { occurrence }\end{array}$} & \multicolumn{2}{|c|}{$\bar{x} \pm$ SE per flock } \\
\hline & 1998 & 1999 & 1998 & 1999 & 1998 & 1999 \\
\hline Roseate Tern only & 6 & 8 & 0.09 & 0.36 & $35.6 \pm 33.0$ & $4.9 \pm 1.6$ \\
\hline Lesser Noddy & 58 & 7 & 0.91 & 0.32 & $167.5 \pm 23.9$ & $59.3 \pm 20.1$ \\
\hline Fairy Tern & 46 & 11 & 0.72 & 0.50 & $12.2 \pm 3.7$ & $10.6 \pm 3.9$ \\
\hline Brown Noddy & 5 & 0 & 0.08 & 0 & $22.8 \pm 4.4$ & 0 \\
\hline Sooty Tern & 15 & 0 & 0.23 & 0 & $64.5 \pm 17.0$ & 0 \\
\hline
\end{tabular}

lieve that prey observed with binoculars were not misidentified. The identification of a few specimens was unclear and these were listed as unidentified. The length of each fish was estimated by comparing it to the culmen length of adult Roseate Terns (ca. 40 mm, Ayrton 1993, and my measurements on four dead adult Roseate Terns), and classified into one of six broad size-categories: $0.5,1.0,1.5,2.0,2.5,3.0$ billlengths.

I assessed Roseate Tern diet with two methods: (1) prey found during daily visits to Roseate Tern study quadrats, and (2) prey used to display to mates and delivered to chicks. Preserved fish specimens were sorted by family, weighed to the nearest $0.01 \mathrm{~g}$ using an electronic balance, and the standard length (from snout to base of caudal fin) was measured to the nearest $0.1 \mathrm{~mm}$ with calipers. Mullids comprised over $90 \%$ of all deliveries (see Results), and chick profitability ( $\mathrm{g}$ of fish ingested chick ${ }^{-1} \mathrm{hr}^{-1}$ ) was calculated using data on mullids only. Wet mass of mullids was regressed on standard length to estimate the mass of each fish that was observed being delivered to Roseate Tern chicks. The best-fit curve obtained was a second-order polynomial $\left(\mathrm{y}=1.242-0.099 \mathrm{x}+0.002 \mathrm{x}^{2}\right.$, where $\mathrm{y}$ is wet mass in $\mathrm{g}$ and $\mathrm{x}$ is standard length in $\mathrm{mm} ; F_{2,104}$ $=1,388, P<0.001, R^{2}=0.96$ ). Mullids delivered were between $0.5-2.0$ bill-lengths; each one of these four size-categories was assigned the standard length of $20,40,60$, or $80 \mathrm{~mm}$ and the mass corresponding $(0.062,0.482,2.502$, and $6.122 \mathrm{~g}$, respectively) was calculated using the above equation.

\section{RESULTS}

\section{FORAGING HABITAT USE AND FLOCK SIZE}

Over the 8 weeks of the 1998 breeding season, I registered 119 weekly observed flocks: 95 in the east-southwest semicircle and 24 in the westnortheast semicircle. Of these, $77 \%$ occurred over blue-water in the east-southwest semicircle. A significantly higher proportion of the flocks with Roseate Terns occurred in the east-southwest semicircle $\left(92 \%, \chi^{2}{ }_{1}=16.0, P<0.001, n\right.$ $=25$ ). Only two Roseate Tern flocks (with two and six individuals) were over the reef area. Over the 3-4 weeks of the 1999 breeding season (so short because Roseate Terns abandoned their clutches and left Aride), no Roseate Tern flocks were detected during the weekly observations.

Daily observed foraging flocks of Roseate Terns were either monospecific or mixed with Lesser Noddies, Fairy Terns, Brown Noddies (Anous stolidus), or Sooty Terns (Sterna fuscata) (Table 1). The monospecific Roseate Tern flocks consisted of 2-10 birds, except on 10 July 1998 when upwelling was observed along the reef edge of the south coast, raising to 200 the number of Roseate Terns in the monospecific flocks. In 1998, Lesser Noddies were present in 58 out of $64(91 \%)$ Roseate Tern flocks, but in 1999 , they were present in only 7 out of $22(32 \%)$ flocks $\left(\chi_{1}^{2}=27.6, P<0.001\right)$. The proportion of Roseate Tern flocks with Fairy Terns did not vary significantly between 1998 and $1999\left(\chi_{1}^{2}\right.$ $=2.59, P>0.10$, Table 1). Surface activity of predatory fish was not detected, and virtually no dense flocks of Lesser Noddies were located around Aride during the 1999 breeding season.

In 1998, flocks that contained both Roseate Terns and Lesser Noddies, the number of individuals of each species was positively correlated (Fig. 2), suggesting that both species were attracted to the same prey patches. Lesser Noddies foraged just over the water surface by contact dipping. Roseate Terns were flying much higher and plunge diving in the center of the flock; Fairy Terns were present mostly on the edge of the flock, swooping down to the water. 


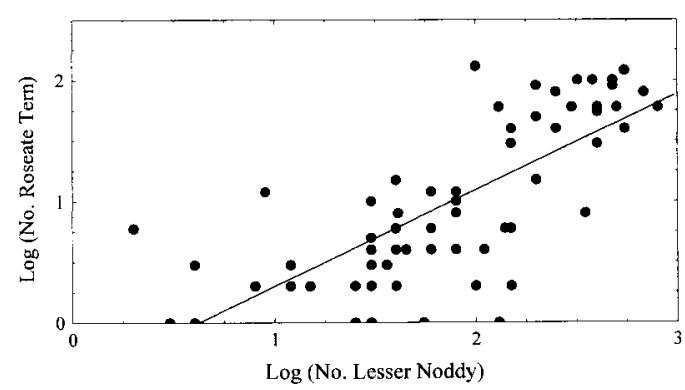

FIGURE 2. Relationship between number of Lesser Noddies and Roseate Terns in mixed-species flocks on Aride in 1998: $\log _{10}$ (Roseate Tern flock) $=-49+79$ $\times \log _{10}$ (Lesser Noddy flock size), $P<0.001, R^{2}=$ $0.56, n=63$.

Flock size $(\overline{\mathrm{x}} \pm \mathrm{SE})$ differed significantly in association with and without predatory fish for both Roseate Terns $(82 \pm 10, n=18 ; 6 \pm 1, n$ $=6$, respectively) and Lesser Noddies ( $380 \pm$ $49, n=18 ; 51 \pm 12, n=39$, respectively; Kruskal-Wallis test for Roseate Terns $H_{1}=36.3$ and Lesser Noddy $H_{1}=26.3$, both $P<0.001$ ). Preycapture attempt frequency by Roseate Terns was significantly higher over predatory fish than when predatory fish were absent (Table 2). The rate of foraging attempts of Roseate Terns in monospecific (= loose and some moderate-density flocks) also was significantly lower than when Roseate Terns were feeding in mixed flocks with Lesser Noddies (= dense flocks; Table 2), presumably because these dense flocks were correlated with the presence of predatory fish.

\section{DIET AND CHICK FOOD PROVISIONING}

Both methods used to assess diet showed that Mullidae (Parupeneus or Mulloidichthys) were the primary prey items taken by Roseate Terns (items found at nests: $1997=81.8 \%, 1998=$ $91.5 \%, n=33$ and 59 , respectively; items displayed to mates and delivered to chicks: $1997=$ $92.8 \%, 1998=97.2 \%, 1999=70.6 \%, n=$ $1,426,1,287$, and 51 , respectively). However, there were differences in secondary prey items between years: Exocoetidae and Belonidae taken in 1997 (9.1\% of the items found at nests) were replaced in 1998 by Scombridae (5.1\%), Clupeidae (1.7\%), and Engraulidae (1.7\%). In 1997, two crustacea and two squid also were observed being delivered to chicks. Prey fish dropped by other inshore feeding species on Aride, Lesser Noddies and Fairy Terns, also comprised mainly mullids (Ramos 1998b).

In 1998 , the daily variation in the amount of food offered to chicks was significantly correlated with the maximum Roseate Tern foraging flock size in the east-southwest semicircle, even after removing the outlier referring to a flock size of 200 Roseate Terns observed on 10 July (Fig. 3). This suggests that the rate of food brought to chicks was largely determined by rates of prey capture over this area (foraging flocks were not evaluated in 1997 and no chick feeding frequencies were obtained in 1999 due to the breeding failure).

\section{SEASONAL AND ANNUAL VARIATIONS IN CHICK FOOD PROVISIONING}

In 1997 and 1998, there were acute but periodic food shortages (1997: 2 July onwards, 1998: 16 July; Fig. 4), whereas in 1999 there was an apparent food shortage throughout the breeding season. In 1997, mean profitability increased daily until 2 July, but overall decreased sharply as chicks grew (Kendall tau correlation coeffi-

TABLE 2. Roseate Tern prey capture attempts in relation to overall flock density and the presence or absence of predatory fish on Aride in 1998. All Roseate Tern dense flocks included Lesser Noddies. $* P<0.001$.

\begin{tabular}{lccc}
\hline \hline & $\begin{array}{c}\text { No. individuals } \\
\text { followed }\end{array}$ & $\begin{array}{c}\text { Observation } \\
\text { time (min) }\end{array}$ & $\begin{array}{c}\text { Attempts min } \\
(\bar{x} \pm \text { SE) }\end{array}$ \\
\hline Density of individuals within a flock & & & $6.54 \pm 0.35$ \\
$\quad$ Dense (with Lesser Noddies) & 54 & 38.3 & $2.99 \pm 0.34$ \\
$\quad$ Moderate & 32 & 33.1 & $1.77 \pm 0.32$ \\
Loose & 10 & 14.3 & $44.7^{*}$ \\
$\quad$ Kruskal-Wallis $H$ & & & $8.26 \pm 0.54$ \\
Habitat & 21 & 15.2 & $2.80 \pm 0.31$ \\
With predatory fish & 36 & 39.6 & $34.5^{*}$ \\
$\quad$ Without predatory fish & & & \\
$\quad$ Mann-Whitney $U$ & & & \\
\hline
\end{tabular}




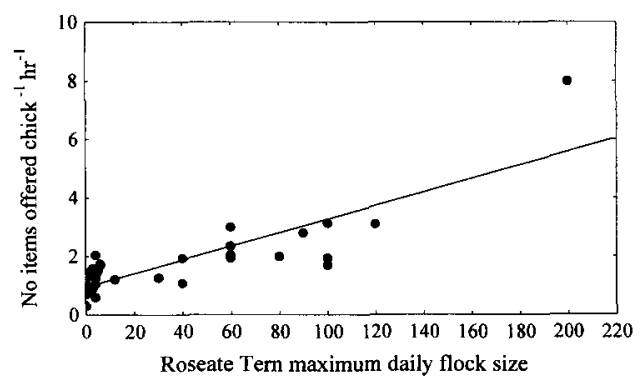

FIGURE 3. Relationship between daily food provisioning of Roseate Tern chicks and maximum daily Roseate Tern flock size registered in the east-southwest semicircle of Aride Island in 1998 (Kendall tau correlation coefficient, $\tau=0.63, P<0.001, n=32$ ). The relationship remained highly significant without the outlier on the far right (Kendall tau, $\tau=0.6, P<$ $0.001, n=31$ ).

cient, $\tau=-0.41, P<0.01, n=25$, Fig. 4), and virtually all chicks died of starvation. Several other observations suggested low food availability in 1997: (1) adults showed submission postures toward birds displaying fish (sometimes robbed with rapid movements), and partners often begged for food that their mates brought to chicks. (2) In July, Roseate Terns returning with fish were harassed consistently by as many as 10 other adults attending chicks nearby. Aerial chases and fights on the ground for a single fish often lasted for up to 5-10 min, with fish changing possession several times. However, the percentage of prey robbed per chick did not differ significantly over the season $(25-30$ June $=$ $3.2 \%, 1-6$ July $=4.7 \%, 7-12$ July $=5.4 \%, 13-$ $18 \mathrm{July}=6.1 \%$, Kruskal-Wallis $\mathrm{H}_{3}=1.5, n=$ 56). (3) The mean percentage of fish other than mullids delivered per chick increased significantly over the same periods $(8.6 \%, 2.9 \%$, $18.4 \%, 23.7 \%$, respectively; Kruskal-Wallis $H_{3}$ $=11.3, P<0.01, n=56$ ), suggesting that Roseate Terns sought alternative prey.

In 1998, the low mean profitability between 1-6 July (Fig. 4) was reflected in weight loss by chicks (Ramos, in press), which suggests prey shortage during this period; but in the overall season there was no variation in the amount of food ingested by chicks (Kendall tau, $\tau=0.01$, $n=35$, Fig. 4). The mean length of mullids given to chicks did not differ significantly as the breeding season progressed for both 1997 (Kendall tau, $\tau=-0.17$ ) and 1998 (Kendall tau, $\tau=$ $-0.18)$.

In 1999, Roseate Terns began laying on 14

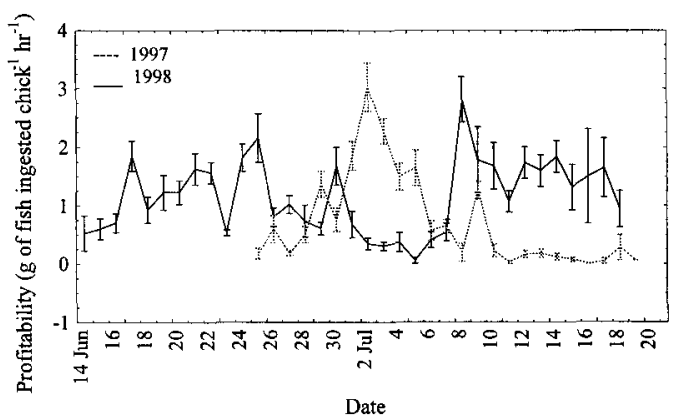

FIGURE 4. Mean \pm SE of Roseate Tern chick profitability through the breeding seasons of 1997 and 1998. Data from the same 5 to 12 chicks (median $=$ 8) watched each day from 07:00-09:00.

June (the latest ever recorded on Aride since 1984), and virtually all abandoned their eggs (only 7 out of 110 eggs hatched). Up to four chicks 0-4 days old were observed for $2 \mathrm{hr}$ on four consecutive days, but only three deliveries were observed. Chicks only 1 day of age were left unattended, suggesting that one of the adults had already deserted or could not obtain fish. All chicks died before reaching 5 days. The breeding success of Lesser Noddies in 1997 was around 30\% (M. Betts, pers. comm.) and in 1999 between $4-10 \%$ (J. Bowler, pers. comm.). Mass chick starvation was recorded for Fairy Terns in both 1997 and 1999.

\section{DISCUSSION}

During the 1998 successful breeding season, Roseate Tern flocks were associated with dense flocks of Lesser Noddies, which in turn were associated with predatory fish. During the 1999 failure season, most Roseate Tern flocks were either monospecific or mixed with Fairy Terns, and no dense feeding flocks or activity of predatory fish were detected. Apparently, in 1998, both species were feeding on schooling fish, made available at the surface by predatory fish (specimens taken from the stomachs of bonito Euthunnus sp. landed on Aride in 1998 also were mullids, the main prey of the terns).

Roseate Tern feeding flocks over predatory fish were significantly larger, with individual birds increasing significantly their foraging attempts than those feeding in the absence of predatory fish. The significantly positive relationship between daily rates of prey offered to chicks and daily maximum size of Roseate Tern feeding flocks strengthens the importance of large dense 
flocks for foraging Roseate Terns on Aride. In 1987, Bullock (1989) recorded only dense flocks of Lesser Noddies and Roseate Terns when associated with shoals of predatory fish, notably Euthunnus sp. The association between predatory fish and Roseate Tern dense feeding flocks on Aride may be obligatory during the breeding season, as is the case in many tropical species (Au and Pitman 1986, Ballance and Pitman 1999), including Roseate Terns in the Caribbean (Shealer 1996).

In 1998, feeding flocks were highly mobile along the coast exposed to prevailing winds. Upwelling and increased productivity might be associated with the winds, which in turn attracts concentrations of underwater predators. Piton (1976) recorded large concentrations both of surface-feeding tuna and seabirds along the edges of the Seychelles in May and June. At this time the boundary between the South Equatorial Current and the Equatorial Counter-current lies at $6-7^{\circ} \mathrm{S}$, the latitude of Central Seychelles (Piton and Magnier 1975). Thus, a relationship between prevailing winds, marine currents, and the activities of predatory fish might exist.

Complete breeding failures of Roseate Terns are common in the Indo-Pacific region (Milton et al. 1996, this study), but uncommon in temperate colonies (Burger et al. 1996). In 15 years of monitoring on Aride, Roseate Terns failed almost completely during half of them (Ramos 1998b). This and other studies on tropical terns (Feare 1976) showed that within a breeding season there are unpredictable food shortages, due to largely unknown factors. Daily variations in the amount of food brought to chicks and intermediate periods of food shortage in 1997 and 1998 suggest that food is unpredictable on a daily and seasonal basis. The fact that Aride Roseate Terns seem to sacrifice egg size for early laying (Ramos, in press) also suggests that food availability is likely to decline through the season. In both 1997 and 1998, periods of good food supply were curtailed by one period of low food delivery. In 1997, the period of low food delivery lasted at least for 2 weeks and virtually all chicks died of starvation, whereas in 1998 it lasted for 6 days and chicks recovered (Ramos, in press). If prey depletion by foraging birds was an important component of periods of food shortage and the seasonal decrease in food availability in 1997, I would have expected the amount of food brought to chicks to decrease steadily over the season. Prey fish may be sufficiently abundant but not made available to terns if predatory fish are absent. Therefore, the movements of predatory fish in the waters around Aride might have been important for the breeding of Roseate Terns in 1997 and 1998. In 1999, however, the food shortage may have been more general (could have been related to a poor recruitment of mullids) than periodic, delaying the breeding season by $2-3$ weeks and causing the abandonment of $90-95 \%$ of the clutches.

It is unknown why all the inshore feeding seabirds on Aride rely so heavily on mullids and why alternative sources of food are apparently scarce. Whereas the breeding success of inshore feeding species was very low in 1997 and 1999, that of offshore feeding species such as Sooty Terns (Sterna fuscata) seemed much higher without any mass chick mortality ever detected on Aride (Bowler and Hunter 1999, J. Bowler, pers. comm.). In terms of prey, temperate and tropical Roseate Tern populations seem to rely on fewer species than other tern species such as Common Terns (Sterna hirundo) and Sandwich Terns (S. sandvicencis), reflecting their specialization on factors that make prey available to them (Safina et al. 1990, Ramos et al. 1998a, Shealer 1998). Whereas temperate Roseate Terns are attracted in particular to physical factors of the ocean (Safina 1990b), tropical populations seem to rely on the presence of predatory fish (Shealer 1996, this study).

The high degree of dependence on multispecies flocks in association with subsurface predators means that foraging flock competition may occur between Roseate Terns and other seabird species, especially Lesser Noddies, with a population on Aride of about 110,000 breeding pairs (Bowler and Hunter 1999). Interference by Brown Noddies can depress foraging success of Roseate Terns in Puerto Rico (Shealer and Burger 1993). Predatory fish themselves have been shown to depress foraging success of Roseate Terns in mixed flocks (Safina 1990a) and contribute to a seasonal decline in prey abundance in temperate areas (Safina and Burger 1985).

The single most important foraging strategy for Roseate Terns and other inshore feeding species on Aride appears to be association with predatory fish. Presumably any persistent feeding flock is associated with predators that prevent prey from escaping to depth (Ballance and Pitman 1999). Breeding failures and periods of 
low chick food delivery were connected with the absence of predatory fish and small loose feeding flocks. Therefore, in order to assist the conservation of Roseate Terns on Aride, information on the ecology and movement patterns of predatory fish are needed. The relative importance of predatory fish versus other factors such as prey recruitment and oceanographic characteristics for foraging Roseate Terns are unknown.

\section{ACKNOWLEDGMENTS}

I am indebted to James Cadbury of the Royal Society for Nature Conservation, U.K., for permission to conduct research on Aride and for financial assistance to travel there. Norman Ratcliffe of the Royal Society for the Protection of Birds, U.K., helped in preparing the trip to Aride. The help, friendship, and suggestions of the wardens of Aride in 1997, Mike Betts and Susan Barclay, and 1998, John Bowler and Janet Hunter, are gratefully acknowledged. Tony Gill of the Natural History Museum (London) identified the mullids, and Chris Feare helped with suggestions and discussions. The friendship of the island wardens, island staff, and volunteers contributed to a good island-life on Aride. Earlier drafts benefited from the comments of David Shealer, Lisa Ballance, Chris Feare, and Luís Monteiro. Finally, I thank my wife for her continuing patience, understanding, and regular phone calls to Aride.

\section{LITERATURE CITED}

Au, D. W., AND R. L. Pitman. 1986. Seabird interactions with dolphins and tuna in the eastern tropical Pacific. Condor 88:304-317.

AyrTon, V. 1993. The 1993 Roseate Tern breeding season-Aride Island Report. R. Soc. Nature Conserv., Lincoln, UK.

Ballance, L. T., and R. L. Pitman. 1999. Foraging ecology of tropical seabirds. Proc. Int. Ornithol. Congr. 22:2057-2071.

Bowler, J., AND J. HunTER. 1999. Aride Island scientific report 1998. R. Soc. Nature Conserv., Lincoln, UK.

Bratthwaite, C. J. R. 1984. Geology of the Seychelles, p. 17-38. In D. R. Stoddart [ED.], Biogeography and ecology of the Seychelles islands. Junk, The Hague.

Bullock, I. D. 1989. Aride Island Nature Reserve scientific report April 1987-April 1989. Part 2: birds, mammals and fish. Wardens' report. R. Soc. $\mathrm{Na}$ ture Conserv., Lincoln, UK.

Burger, J., I. C. T. Nisbet, C. Safina, And M. GochFELD. 1996. Temporal patterns in reproductive success in the endangered Roseate Tern (Sterna dougallii) nesting on Long Island, New York, and Bird Island, Massachusetts. Auk 113:131-142.

DiAmond, A. W., AND R. P. PRYs-Jones. 1986. The biology of terns nesting at Aldabra Atoll, Indian Ocean, with particular reference to breeding seasonality. J. Zool. 210:527-549.
FEaRE, C. J. 1976. The breeding of the Sooty Tern Sterna fuscata in the Seychelles and the effects of experimental removal of its eggs. J. Zool. 179: 317-360.

GoCHFELD, M. 1983. The Roseate Tern: world distribution and status of a threatened species. Biol. Conserv. 25:103-125.

Krebs, J. R., AND A. KaCELNIK. 1991. Decision-making, p. 105-136. In J. R. Krebs and N. B. Davies [EDS.], Behavioural ecology: an evolutionary approach. Blackwell Scientific, Oxford.

MEGYESI, J. L., AND C. R. GRIFFIN. 1996. Breeding biology of the Brown Noddy on Tern Island, Hawaii. Wilson Bull. 108:317-334.

Milton, D. A., G. C. Smith, and S. J. M. Blaber. 1996. Variable success in breeding of the Roseate Tern Sterna dougallii on the Northern Great Barrier Reef. Emu 96:123-131.

Morris, R. D., AND J. W. Chardine. 1992. The breeding biology and aspects of the feeding ecology of Brown Noddies Anous stolidus nesting near $\mathrm{Cu}-$ lebra, Puerto Rico, 1985-1989. J. Zool. 226:6579.

Nelson, J. B. 1983. Contrast in breeding strategies between some tropical and temperate marine Pelecaniformes. Stud. Avian Biol. 8:95-114.

Piton, B. 1976. Particularités météorologiques et océanographiquers du parages du banc des Seychelles (Océan Indien). Cah. Off. Rech. Scient. Tech. Outre-Mer (Océanogr.) 14:289-301.

Piton, B., AND Y. Magnier. 1975. Remarques sur la circulation et les caractéristiques hydrologiques de la couche superficielle entre Madagascar et l'Équateur. Cah. Off. Rech. Scient. Tech. OutreMer (Océanogr.) 13:117-132.

Ramos, J. A. 1998a. Nest-site selection by Roseate Terns breeding on Aride Island, Seychelles. Colonial Waterbirds 21:438-443.

Ramos, J. A. 1998b. The Roseate Tern breeding ecology on Aride Island, Seychelles in 1997. R. Soc. Nature Conserv., Lincoln, UK.

Ramos, J. A. In press. Seasonal variation in reproductive measures of tropical Roseate Terns Sterna dougallii: previously undescribed breeding patterns in a seabird. Ibis.

Ramos, J. A., E. Solá, ANd L. R. Monteiro. 1998a. Prey delivered to Roseate Tern chicks in the Azores. J. Field Ornithol. 69:419-429.

Ramos, J. A., E. SolÁ, F. M. Porteiro, and L. R. MONTEIRO. 1998b. Prey of Yellow-legged Gull, Roseate Tern and Common Tern in the Azores. Seabird 20:31-40.

SAFINA, C. 1990a. Bluefish mediation of foraging competition between Roseate and Common Terns. Ecology 71:1804-1809.

SAFINA, C. 1990b. Foraging habitat partitioning in Roseate and Common Terns. Auk 107:351-358.

SAFINA, C., AND J. Burger. 1985. Common Tern foraging: seasonal trends in prey fish densities, and competition with bluefish. Ecology 66:14571463. 
Safina, C., R. H. WAGNER, D. A. WitTing, AND K. J. SMITH. 1990. Prey delivered to Roseate and Common Tern chicks; composition and temporal variability. J. Field Ornithol. 61:331-338.

SHEALER, D. A. 1995. Comparative foraging ecology of Roseate and Sandwich Terns in Puerto Rico and its relation to breeding performance. Ph.D. diss., Rutgers Univ., New Brunswick, NJ.

SHEALER, D. A. 1996. Foraging habitat use and profitability in tropical Roseate Terns and Sandwich Terns. Auk 113:209-217.
Shealer, D. A. 1998. Difference in diet and chick provisioning between adult Roseate and Sandwich Terns in Puerto Rico. Condor 100:131-140.

ShEAlER, D. A., AND J. Burger. 1993. Effects of interference competition on the foraging activity of tropical Roseate Terns. Condor 95:322-329.

Smith, M. M., AND P. C. HeEmstRa. 1986. Smiths' sea fishes. Springer-Verlag, Berlin.

Warman, S. R., AND D. TODD. 1984. A biological survey of Aride Island Nature Reserve, Seychelles. Biol. Conserv. 28:51-71. 